\title{
Style in Christian and Islamic Sermons: A Linguistic Analysis
}

\author{
Acheoah, John Emike PhD' ${ }^{1}$, Hamzah Abdulraheem ${ }^{2}$ \\ ${ }^{1}$ Department of Language and Communication Studies, Faculty of Arts, Management and Social Sciences, \\ Federal University, Dutsin-ma, Nigeria \\ ${ }^{2}$ College of the Humanities, Department of Languages, Al-Hikmah University, Ilorin, Nigeria
}

\begin{abstract}
The study is a stylistic analysis of language use in religious discourse. It is a very significant study because apart from using an integrative discursive approach to investigate phenomena, we do not know of any study that uses a contrastive approach to analyze style in Christian and Islamic sermons. Selecting and organizing language, as well as deviating from its norms is the concern of style. The study investigates linguistic dimensions of Christian and Islamic sermons, hinging on the Communicative Model stylistic theory as analytical framework, although insights from pragmatics and rhetoric (discrete fields of knowledge) give the study illuminating directions. The findings include: religious sermons convey sacred messages; Christian and Islamic sermons are conveyed with similar stylistic devices; the major areas of divergence in the sermons of both religions is that they use different nomenclatures and contextual structures.
\end{abstract}

Keywords: Christianity, Islam, sermon style, stylistics, pragmatics.

\section{INTRODUCTION}

Religion is a social system that regulates man's existence ${ }^{1}$. This paper investigates the stylistic features of Christian and Islamic sermons. The study generates 20 data from three sermons: Pastor W.F. Kumuyi's sermon, 'The Rewardable Commitment of a Focused Life', Bishop David Oyedepo's sermon, 'The Spirit of Meekness' and Prophet Muhammed's sermon, 'The Last Sermon'. In both religions, sermons serve as a means of teaching the doctrines of God either in written or spoken discourse. Christian sermons are basically delivered in churches, although other public places are sometimes used for this purpose. Islamic sermons are delivered in the mosque in case of Jumu'at (Friday) religious service, and on a praying ground in case of the annual rituals: (idul-fitri festival prayer that commemorates the end of Ramadhan fasting) and idul-adha or idul-Kabir (festival of the sacrifice).

\section{STYLE AND STYLiSTICS}

Banjo (1982) defines stylistics as the exhaustive study of the role of language in literary works. In stylistics, we find a meeting point between literary and non-literary study of texts. Having a clear understanding of the term 'stylistics' therefore presupposes a clear understanding of 'style' which refers to the way language is used in a given context, by a given person, for a given purpose 2 .

\section{RELIGION AND SERMON}

During the time of Prophet Muhammad, and the four rightly guided caliphs, sermons were given during important occasions. One of such occasions was the Prophet's farewell pilgrimage when he delivered 'The Last Sermon' or 'The Farewell Sermon' in February 632 AD, in the Uranah valley of Mount Arafa. Delivered over 1,400 years ago, the freshness and relevance of 'The Last Sermon' to contemporary social problems qualifies it to be regarded as an all-time exhortation that consolidates Monotheism in the heart of the Muslims, averts division, restores calmness in family relation (Darussalam, 2013:11), upholds equity and justice and forbids adultery, indecency, usury and bloodshed.

From ages undefined, delivering sermons was a crucial practice in Christendom. Christianity began 2000 years ago in Judea (now Israel). The religion is a product of the evangelical ministry of Jesus who with His disciples (after the disciples had witnessed the signs and wonders which Jesus did), challenged the religious authorities of His time, to practice true Christian religion by desisting from self-righteousness and serve God according to His Word. Broom and Selznick (1963) view religion as a belief in God or gods. This incorporates the doctrines and processes of

${ }^{1}$ Corresponding Author: actualemike@gmail.com 
worshiping the gods or God; having faith in deities that man cannot see3. Alanamu and Mohammed (2006) submit that religion can be understood in two perspectives: the material sense which refers to religious establishments (institutions and officials as well as social groups and movements); and the spiritual sense (social behavior helping believers to organize their everyday life). Religion is one of the agents of socialization. Broom and Selznick (Ibid.) note that religion is a component of every human society, although not all individuals are religious ${ }^{4}$.

Okau et al (2003) cite Gordon Marshall who states that the scientific study of religious institutions, beliefs, and practices had its origin in Marxism and the neo-Hegelian critique of religion, but is primarily associated with the late $19^{\text {th }}$ century research into religious phenomena by Emile Durkheim, George Siiel, Robertson Smith, Ernst Troeltsch, and Max Weber. According to Emily Durkheim, as cited in Okau et al (ibid.) religion may be defined as 'a unified system of beliefs and practices relative to sacred things, uniting into a single moral community all those who adhere to those beliefs and practices.' It encapsulates creeds, beliefs, symbols and practices that clearly explain the nature and mystery of existence. Naik (2007:3) opines that 'the history of man further punctuates the belief that religion is an integral part of human life and one of the distinguishing features of human civilization.'

\section{THEORETICAL FRAMEWORK}

For the analysis of corpora, this study hinges on The Communicative Model stylistic theory propounded by Lawal (2012). This theory is briefly explained below:

\subsection{Lawal (2012)}

Lawal (2012) posits that the Communicative Model theory is eclectic in nature because it is the totality of the submissions of predating stylistic theories. The theory explains the interaction between message and medium through socio-linguistic and rhetorical devises. Elements in the theory include

\section{SPEAKER OR WRITER}

2. MESSAGE (i.e.) writer's or speaker's impression in the form of ideas, beliefs, knowledge, feelings and attitudes, etc. on the one hand, or listener's or reader's impression decoded in the form of ideas, beliefs, knowledge, feelings, etc.;

3. MEDIUM i.e. writer's or speaker's expression encoded in the form of: (i) A rhetorical mode (the primary stylistic device which incorporates linguistic norms and directs pragmatic interpretation of textual properties); (ii) Linguistic 'norms', constants, variants, and deviants.

\section{Methodology}

We examine 20 utterances (micro-structures), mentioning the stylistic features therein and the functions of such features. Utterances 1-10 are taken from two Christian sermons while Utterances 11-20 are taken from an evergreen Islamic sermon. The analysis will not only overview pragmatic components in the data (as necessitated by the theoretical framework of the study), but will also investigate the similarities and differences between Christian and Islamic sermons.

\subsection{Presentation of Data}

Below are 10 utterances to be analyzed from the two Christian sermons

Utterance 1

'We are looking at a life you are committed to living.'

Utterance 2

'You and I have our choices to make.'

Utterance 3

'If you look at God, look at what people cannot see - the riches in glory.'

Utterance 4

'If you want to live a glorious life, distractions will come, persecutions will come.'

Utterance 5

'The life you want to live will take courage.'

Utterance 6 
'Access to unlimited revelation is your portion.'

Utterance 7

'All who are not married yet, by next Shiloh you are fully married.'

Utterance 8

'End of bareness for everyone participating in Shiloh.'

Utterance 9

'All the atrocities the enemy caused in Job's life are by the bait of fear (Job 3:24-25).'

Utterance 10

'Somebody believe? Let me hear your loudest Amen.'

The following are utterances $11-20$ taken from the Islamic sermon, for integrative, discursive analysis in this study:

Utterance 11

'O people, lend me an attentive ear, for I know not whether, after this year, I shall ever be amongst you again. Therefore, listen to what I am saying to you very carefully and take these words to those who could not be present here today.'

Utterance 12

'O people, just as you regard this month, this day, this city as sacred, so, regard the life and property of every Muslim as a sacred trust. Return the goods entrusted to you to their rightful owners. Hurt no one so that no one may hurt you.'

Utterance 13

'Remember that you will indeed meet your Lord, and that He will indeed reckon your deeds. Allah has forbidden you to take usury (interest), therefore all interest obligation shall henceforth be waived. Your capital, however, is yours to keep.'

\section{Utterance 14}

' $O$ Men the unbelievers indulge in tampering with the calendar in order to make permissible that Allah forbids and to forbid that which Allah has made permissible. Beware of Satan, for the safety of your religion, he has lost all hope that he will ever be able to lead you astray in big things, so, beware of following him in small things.'

Utterance 15

'O people, it is true that you have certain rights with regard to your women, but they also have right over you. Remember that you have taken them as your wives only under Allah's trust and with His permission. If they abide by your right then to them belongs the right to be fed and clothed in kindness. Do treat your women well and be kind to them for they are your partners and committed helpers. And it is your right that they do not make friends with any one of whom you do not approve as well as never to be unchaste.'

Utterance 16

'O people, listen to me in earnest, worship Allah, say your five daily prayer (Salah), fast during the month of Ramadan, and give your wealth in Zakat, perform Hajj if you can afford to.'

Utterance 17

'All mankind is from Adam and Eve; an Arab has no superiority over a non-Arab, nor a non-Arab has any superiority over an Arab. Also, a white has no superiority over a black nor a black has any superiority over a white except by piety and good action. Learn that Muslim is a brother to every other Muslim and that Muslims constitute one brotherhood. Nothing shall be legitimate to a Muslim which belongs to a fellow Muslim unless it has been given freely and willingly. Do not, therefore, do injustice to one another.'

Utterance 18

'Remember, one day you will appear before Allah and answer for your deeds. So, beware. Do not stray from the path of righteousness after I am gone.'

Utterance 19

'O people, no Prophet or Apostle will come after me and no new faith will be born, reason well, therefore, O people and understand my words which I convey to you. I leave behind me two things: The Qur'an and my Example, the Sunnah. If you follow these you will never go astray.' 


\section{Utterance 20}

All those who listen to me shall pass on my words to others and those to other again; and may the last ones understand my words better than those who listen to me directly. Be my witness O Allah, that I have conveyed your message to your people.'

\subsection{Analysis of Data}

This section is a linguistic analysis of Christian and Islamic sermons, towards a contrastive conclusion.

\subsubsection{Christian Sermon}

The analysis of Utterances 1-0 is as follows

Utterance 1 begins the sermon with an attention-arresting syntax; the first clause has the clause structure 'auxiliary + verb-ing'. The structure depicts the urgency and speed of the message. Intended communicative effects may not be achieved if the Preacher uses the clause structure 'verb + to' which is appropriate for a sermon that is to begin. Thus, good introduction is a communicative devise in Utterance 1. The use of 'we' and 'you' is of credit; the Preacher shifts from the singular to plural form to evoke the emotion of the audience. Personal pronouns of diverse kinds (personal, reflexive, etc.) are common in Christian sermons because they characterize the evergreen sermons of Jesus Christ as shown in the Holy Bible. Without the use of personal pronouns, there cannot be effective speakerhearer discourse; that is, it will be difficult to evoke hearers' emotion pungently. Below are scriptural examples of personal pronouns which I have underlined

\section{Matthew 5:16}

'Let your light so shine before men, that they may see your good works, and glorify your Father which is in heaven.' Matthew 6:19-21

'Lay not up for yourselves treasures upon earth, where moth and rust doth corrupt, and where thieves break through and steal. But lay up for yourselves treasures in heaven, where neither moth nor rust doth corrupt, and where thieves do not break through nor steal: For where your treasure is, there will your heart be also.'

Luke 10:19

'Behold, I give unto you power to tread on serpents and scorpions, and over all the powers of the enemy; and nothing shall by any means hurt you.'

Luke 16:15

'And he said unto them ye are they which justify yourselves before men; but God knoweth your hearts: for that which is highly esteemed among men is abomination in the sight of God.'

John 14:4

'Abide in $\underline{m e}$, and $\underline{I}$ in you. As the branch cannot bear fruit of itself, except it abide in the vine; no more can ye, except ye abide in me.'

Usual collocates in the utterance include 'life' and 'living'. These collocates amplify the message.

The personal pronouns 'you', 'I' and 'our' are used to make a direct call to action; they substitute 'humanity' in the discourse. This is the way the Preacher chooses to tell the audience that 'God is not a respecter of persons'. The message is crucial, so the preacher inflates the language to make the audience fulfill the spiritual conditions for God's blessings. Fowler (1981:28) posits that 'Linguistic structure is not arbitrary, but is determined by the functions it performs.' Utterance 2 is a simple sentence and a Declarative (speech act). Declarative enables the Preacher to state God's injunctions and the attendant blessings which are products of their obedience to such injunctions.

Usual collocates abound in Utterance 3: 'look' and 'see'. 'God' is used as a substitute for 'riches in glory'. Similarly, the expression 'what people cannot see' substitutes 'riches in glory'. The Preacher uses both specific syntax and repetition (the repetition of the verb 'look') to make a direct call to action. The audience is called to begin a new approach to spiritual living; an approach that is faith-driven. The syntax shows an emphatic clause; the sentence begins with a subordinate clause, 'If you look at God' and then contains an extended main clause. Indeed, the repetition of 'look' in the syntax creates sound effect, besides arresting listeners' attention. The function of the 
conditional clause in Utterance 4 is unusual, but theme-driven. Such a clause is dominantly used in Christian sermons, to state the condition(s) for God's promises to be fulfilled in a person/believer. But the encoder uses it to state the inevitable products of a true Christian life (a deviant use). The encoder does not mean that distractions and persecutions are conditions for living a glorious life. The repetition of 'will come' in the syntax reiterates the message via substitution; distractions and persecutions are thematic substitutes. The Preacher means that persecutions are aimed at distracting the Christian pilgrim. Utterance 4 is an Ascriptive (a speech act category which ascribes certain qualities to the Christian race). Ascriptive is significantly used to expand and explain the message. The adjective 'glorious' captures the bliss, victory and perfection of a Christian life. Allan (1986) submits that speech acts are directed to states-of-affairs called 'worlds-spoken-of'. The Preacher therefore uses an adjective to ensure that the message has a contextual structure rather than existing in a vacuum.

Utterance 5 shows tripartite speech acts sequenced towards the speaker's illocutionary goal. The speaker could have said: 'If you want to live the life...' so as to give the listeners option. This speaker chooses a clause structure (a conditional clause without the use of the usual markers) that invokes, legislates, imposes, and recommends a pattern of Christian life to the audience. Indeed, the clause-structure is presupposition-informed. The presuppositions of a speaker are the propositions which he takes for granted as part of the background of the communication (discourse). In Utterance 5, the speaker presupposes therefore that the audience wants good, victorious and blessed life.

As in Utterance 4 where the adjective 'glorious' concisely describes a state-of-affairs, the adjective 'unlimited' in Utterance 6 is potently descriptive. The encoder uses it in the SVC (subject-verb-complement) syntax to overstate the message; my argument is that God cannot reveal all His mysteries to man (generic). Therefore, Christian religious discourse is a demonstration of profound pragma-semantic communicative strategies towards rhetoric (persuasive speech). In religious discourse, illocutionary forces (speech acts) are intentionally directed towards preachers' messages. Such preachers select agencies of communication (linguistic structures) towards persuasion, relying on presuppositions and mutual knowledge they have with their audience. Therefore, the language of religious discourses has obvious communicative potency, and enables preachers to establish substantive relationship with their congregation as they select speech acts appropriately. Informatives are dominant in religious discourse and such Informatives are given figurative and rhetorical features. Religious speakers exploit natural human tendencies by situating their messages in varied social, pragmatic and psychological contexts.

Speaker-hearer shared knowledge informs the use of Shiloh (biblical allusion and reminiscence) in Utterance 7. Considering the topic of the sermon, Utterance 7 suggests thematic shift informed by the need to make the message all-encompassing. The linguistic items as well as the message in the utterance do not align with the topic 'The Spirit of Meekness'. I postulate therefore, that the Christian sermon is delivered to different categories of audience, and invariably, the pressing needs of the different categories of audience differ. For example, as part of the audience of a sermon, the young adults may be in serious need for future partners (in marriage) while the youths may be in urgent need for admissions into higher institutions. Other categories of audience may need promotion in work places or financial breakthrough. Therefore, the encoder employs thematic shift as a component of style. The syntax shows a conditional clause (the condition for those not yet married to become fully married, is 'attending next Shiloh') without the use of the conjunctions that mark such a clause. Obviously, Utterance 7 is an indirect call to action.

Besides sharing features of Utterance 7, Utterance 8 is a sentence fragment. This structure is functional. The speaker tries to say a lot in limited time and also vary his linguistic patterns.

Utterance 9 reveals biblical allusion. Biblical allusion is common in the sermon, and by extension, in Christian sermons. Knowing that the Christian audience is aware of Job's case or experiences as stated in the Holy Bible (speaker-hearer shared knowledge), the Preacher conveys the message without communication breakdown. By alluding, the Preacher makes an analogy. Allusion clarifies the message, makes the sermon less boring and expands it.

The interrogative unit of Utterance 10 shows the omission of an auxiliary operator. Often, speakers use sentence fragments, depending on the constraints of the discourse they engage in. The syntax in the different corpora accentuates the Preachers' linguistic prowess. Contemporary English grammar contains what is called 'acceptable fragments'.

\subsubsection{Islamic Sermon}

Utterances $11-20$ are analyzed as follows 
Utterance 11 opens the sermon with a call: "O people, lend me your ears ..." 'People' (the companions of the prophet who constituted the immediate audience) is the addressee and is given a thematic focus as the first element in the imperative clause. This clause is preceded by the vocative ' $\mathrm{O}$ ', which is an interpersonal theme. Note that ' $\mathrm{O}$ people', with its variant form, 'O men', is repeated six (6) times in the sermon. It is a rhetorical device, consisting of a requestive speech act asking to the people's attention. According to Omoloso (2013:14), the generative power of 'O people' in the opening speech and its repetition in the sermon is that the prophet 'wanted to make sure that his speech had the necessary illocutionary force potentials in order for it to have the intended perlucationary effect on the people'.

Doi (1977:82) asserts that the sermon focuses on fifteen (15) social issues relating to robust and healthy human relations, establishing peace, justice and security in the world. Stylistically therefore, the dominant noun choice in the sermon is abstract noun which points to concepts emphasized by Prophet Muhamad. These concepts constitute issues that the prophet discussed in the sermon: worship, trust, piety, brotherhood, love, justice, wealth sharing through Zakat (alms giving) and the sanctity of human life are genuinely advocated for; on the other hand, inequality, injustice, killing, racism, tribalism, ethnicity, double-standard life, usury and poverty are vehemently condemned. The prophet exhorts the entire Muslims to live as one brotherhood (as in Utterance 17).

Furthermore, the abstract nouns and the entire linguistic choices of the sermon stress the universality of moral philosophies and ideological inclinations of Islam. It is a religion that has divine regulations in every facet of human existence: at the family unit, socio-economic matters and political affairs. Like in all religious discourses, linguistic patterning in the sermon explicates divine regulations. At the level of mood choices, 'The Last Sermon' contains 93 clauses; 64 are declarative clauses, while 29 are imperative clauses. Of course, (except in rare cases), declaratives are always the predominant mood pattern in all texts, as convey information to the audience. Thus, declarative clauses convey divine messages that are meant to regulate the lives of the listeners in Mount Arafa and the generations of Muslims who follow them. In the following simple, but highly penetrating declarative clauses, (with the except a clause), the prophet establishes the complementary duties of husbands and wives the family (Utterance 15). On the other hand, imperative clauses instruct or order the other person to carry out certain commands and obligations. The sermon strings together chains of imperative clauses which foreground the divine injunctions to be obeyed by the listeners. Such imperative clauses equally accentuate the persuasive feature of religious sermons. In 'The Last Sermon, the Prophet aptly summarizes and reiterates the Five-Pillars of Islam, using imperative clauses as in Utterance 16. Stylistically, the Prophet underscores the divine message encapsulated in the above imperative clauses through: (i) the use of parataxis to extend and give equal status to the Five- Pillars of Islam; (ii) the use of imperative clauses of obligation that signal high-value modal involvement. In fact, virtually all the imperative clauses signal high-value modal involvement. Other similar abound in Utterance 14.

The directive acts in the declarative clauses produce perlocutionary effects (see Austin 1962 for insights on speech act taxonomy) on the listeners such that they would be persuaded, if not compelled, to live an orderly life that guarantees trust, peace, justice and uprightness.

The conditional statement 'if you follow these' is placed in the initial element (for thematic reasons), before the main or independent clause 'you will never go astray'. Therefore, the marked conditional clause stylistically conveys the semantic import of the conditional clause; a condition that must be met before the eternal bliss and blessings of paradise can be attained. Indeed, appealing to faithful to refrain from evil acts, and contend for righteousness that would earn adherents the pleasures of paradise, are the central messages in religious sermons.

At the level of textual organization, repetition and conjunction are two cohesive devices that anchor the messages of the sermon. 'People', 'Allah' and 'Muslims' are the repeated lexical items. 'Allah' is repeated in Utterances 13, 14, 15, 16, 18 and 20. The word 'Muslim' and its plural form, 'Muslims', are repeated several times. Contextually speaking, 'people' and 'Muslim' are synonymous. This implies that the Prophet was giving a recap of the message and teachings of Allah (Islam) to the entire mankind.

Before the Prophet delivered the sermon, he had had the vision of his imminent death. So on the occasion of his last Hajj, he summarized the main injunctions of Islam. Hence, the lexical repetition of 'Allah', 'people' and 'Muslims', underscores the content meaning of the sermon and stylistically foregrounds Monotheism (the worship of Allah alone) in Islam. Consider the repetition of identical clausal patterning 


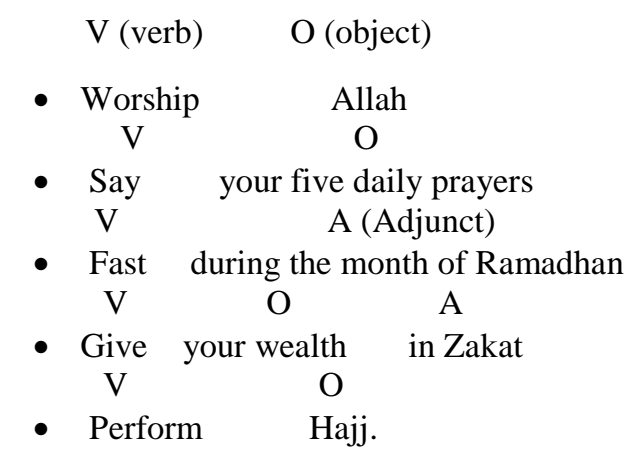

In Islam, the illocutionary acts of 'worship', 'say' 'fast' 'give' and 'perform' are to be religiously practiced for the before one can attain rewards from Him. So, the repeated clausal patterning above further stresses Monotheism in Islam. Thus, through lexical and clausal repetitions, the Prophet reiterated the main components of his twenty-three years Prophet-hood.

As cohesive devices, conjunctions signal textual transition which links part of clauses into nexuses. The relations are either hypotactic and paratactic. They extend the domain of the grammatical structure of the clause nexuses through elaboration, extension and enhancement (cf. Halliday and Mathieson, 2004:540).

In 'The Last Sermon', both extending and enhancing clauses are identified. Extension types conjunctions which enhance the span of the text are 'and', 'also' 'nor' 'yet' 'except' and 'however'; 'And', 'also' and 'nor' are positive additions. In other words, the conjunctions positively extend the idea in the first clause by adding another one to give a balanced (equal) status. Utterance 17 is illustrious.

The Prophet vehemently lampoons racial superiority, ethnic and tribal bigotry. He regards Muslims as having equal status before Allah. The additive conjunctions 'nor' and 'also' which signal clause of equal status, also explicate the equality of status. However, the proposition, of the clause complex are further extended by 'except' which varied the propositions.

In addition to additive type of conjunction, the text exhibits an extension type of conjunction known as adversative. 'But' and 'however' are adversatives that are used in the text. The Prophet explains in Utterance 13

Allah has forbidden you to take usury (interest), therefore all interest obligation shall henceforth be waived. Your capital, however, is yours to keep.

Although the prophet decries taking usury in business and banking transactions (note the semantic import of forbidden), he (through indirect illocutionary strategy act expressed in 'Your capital, however, is yours to keep') sanctions lawful business (trading). Thus, additive and adversative types of conjunction discussed above create cohesion and extend the propositions in the paratactic clauses.

The types of enhancement that create cohesion in our sampled text are the causal-conditional. Causal-conditional conjunctions in the sermon are 'so', 'therefore', 'then', (causal) and 'if' (conditional). 'Therefore' is fore-grounded in the text as it is repeated 4 times. According to Halliday and Mathiessen (ibid.), 'therefore' shows that a text is a persuasive one, where the speaker presents arguments and appeals to the reader to accept it. Such arguments are found in the sermon as evident in Utterance 19. The argment is premised upon the initial two declarative clauses. The strength of the argument is linguistically conveyed by: (i) the vocative ' $\mathrm{O}$ ', which signals thematic prominence; and (b) the additive conjunction 'and', which links the two clauses. Having laid the basis for the argument, the Prophet concludes by appealing to the sense of reasoning and conviction of the listeners. He hinges on two imperative clauses: 'reason' and 'understand', which encode command and obligation that have high-value modal commitment. Thus, in religious sermons, modality is a persuasive strategy and a linguistic element for encoding the ideological dispositions of the speaker or writer.

Another causal conditional type of conjunction expressed in the text is 'if'. The Prophet gives a condition that would make the Muslims in particular, and humanity in general, to remain in the straight-guided path (Utterance (19).

Indeed, the additive conjunction 'and' in Utterance 20 ushers a prayer (requestive). However, the speaker subtly uses it as a covert, idiosyncratic clause of condition; he asserts the condition for some category of listeners to be more blessed than others, and this condition is 'being among later-listeners to the sermon'. 


\section{Discussions AND CONCLUSIONS}

Stylistics is a registration of a writer's artistic prowess in communication of themes, and this is achieved through the manipulation of the linguistic repertoire at the disposal of the writer. Selecting or ordering language, as well as deviating from the norm, is the concern of style. Leech and Short (1981) posit that style can be applied to both spoken and written, both literary and non-literary varieties of language, but by tradition, it is particularly associated with written literary texts. Abraham (1981) opines that the characteristic of a work may be analyzed in terms of: its diction, or choice of words; its sentence structure and syntax; the density and types of its figurative language; and its rhetorical aims and devices. Vocabulary modification is the most obvious and accessible aspect of style.

The paper examines the communicative features of Christian and Islamic sermons with a view to establishing areas of convergence and divergence. We find out that different stylistic devices convey messages in religious discourse such as a sermon. Often, speakers' choices are informed by audience, message, idiosyncrasy and other discourse constraints. In both Christian and Islamic sermons, the core is that exhortation to obey the injunctions of God or Allah is made. The rewards of obedience and disobedience are often spelt out by the speakers, from either the Holy Bible or the Holy Quran.

The discourses are often delivered in persuasive mode via similar linguistic agencies: themes-driven syntactic patterns, potent communicative conjunctions, speaker-bases speech act selection and sequencing, appealing repetitions, versatile clause structure, allusions, analogy, to mention but a few. However, the contextual structures (world-spoken-of as posited by Allan 1986) and nomenclatures vary in the sermons of both religions; ; wile an Islamic speaker selects states-of-affairs that are in conformity with the injunctions of Islam, the Christian speaker chooses contextual structures (facets of life/practices) that are Scriptural. The features of Christian sermons, according to Babatunde (1998:40), include acknowledgment of the existence of God, rhetorical devices that arrest audience attention, stories, anecdotes and allusions. Added to these features are simple lexical choices, sentence structures and figurative language, especially metaphor, simile and symbolism, which aid clarity of expression.

\section{Notes}

1. Religion is a social system that regulates man's existence. It encapsulates creeds, beliefs, symbols and practices that clearly explain the nature and mystery of existence. According to Naik (ibid.:3), the history of man farther punctuates the belief that religion is an integral part of human life and one of the distinguishing features of human civilization.

2. In stylistics, texts of various disciplines can be seen as "language in action". Having a clear understanding of the term "stylistics" therefore presupposes a clear understanding of "style" which refers to the way language is used in a given context, by a given person, for a given purpose.

3. Forms of religion include Christianity, Islam, Hinduism, Judaism, Totemism, etc.

4. Giddens (1993) has contended that difficulty abounds in attempts to define religion, and this is because of the multiplicity in religious beliefs and organizations.

5. For example, in Utterance fifteen, polygamy is advocated by the speaker, since it is an Islamic practice. However, the Christian speaker (even if the topic concerns marriage), will not recommend the practice.

\section{REFERENCES}

[1] Abrams, M. H. A Glossary of Literary Terms (Chicago: Hold, Renchart and Winsten, 1981):62.

[2] Alanamu, A. \& Muhammed, Y. (2006). "Religious Violence: Implications and Options for Sustainable Development" in Saliu et al Democracy and Develpment in Nigeria: Social Issues and External Relations. Ilorin: Faculty of Business \& Social Sciences. P. 137.

[3] Allan, Keith. 1986. Linguistic Meaning Vols. I and II. London: Routledge and Kegan Paul.

[4] Babatunde, S. T. (1998) "Persuasion in Christian Religious Speeches - A Speech Act Analysis" in Gbenga Fakuade (Ed) Studies in Stylistics and Discourse Analysis. Yola: Paraclete Publishers.

[5] Banjo, Ayo. "The Linguistic Factor in African Literature: A Key Note Address". Paper presented at the 7th Ibadan African Literature Conference, University of Ibadan, 1982.

[6] Broom \& Selznick. (1963). Sociology: A Text with Adapted Readings, 3rd Edition New York: Harper \& Row Publishers.

[7] Darussalam.com (2013) Selected Friday Sermons. Riyadh: Darussalam. 
[8] Doi, A.R.I, (1979). The Cardinal Principles of Islam. Lagos: Islamic Publication Bureau. Giddens A. (1993) Sociology, 2nd Edition. U.K.: Polity Press.

[9] Halliday and Matthiessen (2004) Functional Grammar. 3rd Edition: London: Edward Arnold.

[10] Lawal, Adebayo (2012). "Aspects of a Stylistic Theory and the Implications for Practical Criticism." In Adebayo Lawal (ed.), Stylistics in Theory and Practice. Ilorin: Applied Linguistics Study Group (ALSG), University of Ilorin, p. 38.

[11] Leech G., Michael S. (1981). Style in Fiction. London and New York: Longman.

[12] Naik, Z. (2007). The Concept of God in Major Religions. Riyadth: Darussalam.Okau, A. et al (2003). Readings in Current Sociology. Makurdi: Aboki Publishers.

[13] Omoloso, R. K. (2014). "The Universality of "The Last Sermon": A Universal Pragmatic Analysis". A Paper Presented at a National Conference Themed: As-Siratun-Nabawiyyah as Panacea for the Revival of the Nigerian Nation, organized by the Department of Islamic and Arabic Unit, Al-Hikmah University, Ilorin, Nigeria. 